\title{
亜鉛残渣浸出液の脱Asについて
}

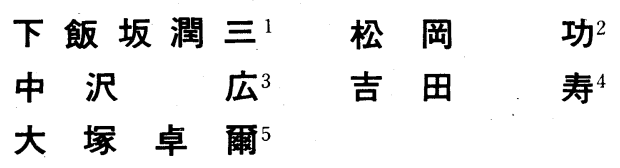

\section{1. 緒一言}

湿式亜鉛製鍊における浸出残渣から，Zn および他の有 価金属を回収するため, $\mathrm{Fe}$ も含めて稀硫酸に可溶な成分 をすべて溶かし出し，しかるのち Fe を加水分解により沈殿 除去する方式が検討され，加水分解反俯の違いによりへマ タイト法, ジャロサイト法, ゲーサイト法等が操業に移さ れている。

原料鉱石中にAsがある場合, As は Fe 沈殿中に共沈し, $\mathrm{Fe}$ の資源化を考えたとき，障害となる場合が生じ， $\mathrm{Fe}$ の 沈殿工程以前にAsを除去する技術の確立が望まれる。廃水 中のAs の除去法としては,イオン交換法, 活性炭吸着法, 硫化物沈殿法 ${ }^{3)}$ などもあるが， $\mathrm{Fe}^{3+}, \mathrm{Al}^{3+}$ などの水酸化物 による共沈法がもつとも一般的に行なわれている。水酸化 物共沈法は操作が単純であり, 脱鉄工程原液に直接適用の 可能性がある点有利であると考えられるので，亜鉛残渣浸 出夜 (以下, 浸出夜と略す) 中の $\mathrm{Fe}^{2+}$ の一部を炭酸カルシ ウム (以下, 炭カルと略す) 共存下で $\mathrm{Fe}^{3+}$ に空気酸化し, 直ちに生成する水酸化第二鉄にAsを共沈させる方法につい て検討を行なつた。浸出から脱鉄までの一連の工程は高温 下で行なわれているので，とくに高温下での脱Asについて 検討したが，比較のために常温での実験も行なつた。

\section{2. 実験試料および方法}

試料水として市販一級試薬の硫酸第一鉄, 硫酸要鉛, 硫 酸カドミウムおよび化学用三酸化七素を用い, 所定の濃度 に調製した人工溶液の他に，秋田製鍊（株）飯島製鍊所の 脱銅液に炭カルを添加し， pH を4.5 とした後沪過し， そ の洰夜 (以下，一次中和水と呼ぶ）を用いた。第 1 表に試 料水の分析値を示す。

実験は次の手順で行なつた。試料水 $400 \mathrm{ml}$ を $500 \mathrm{~m} l$ のビーカに採取し，マグネチックスターラて靦拌しながら

\footnotetext{
* 1978 年 10 月 26 日受理 昭和 52 年 4 月 日本鉣業会春季大会にて

1. 正会員 工博 東北大学教授 工学部資源工学科

2. 正会員 工博 東北大学助教授 工学部資源工学科

3. 准会員 岩手大学助手 工学部資源開発工学科

4. 准会員 東北大学大学院生 工学部資源工学科

5. 正会員 秋田製鍊株式会社飯島製鋅所長

a) 実操業ではこの工程で $\mathrm{Ga}$, Inの回収と一部のAs が除かれている。
}

所定量の炭カルを添加した後, Denver 型浮選機に移し, 10 分間空気混和を行なつた。浮選機のセル容量は $450 \mathrm{~m} l$, インペラ径は $3.9 \mathrm{~cm}$ ，インペラ周速度は $280 \mathrm{~m} / \mathrm{min}$ であ る。高温 $\left(80^{\circ} \mathrm{C}\right)$ での実験では, ビーカに採取した試料水 を温浴中で $80^{\circ} \mathrm{C}$ に加温した後, 炭カルを添加し, 自動温度 調節器に連結したヒータ $(200 \mathrm{~W})$ をとりつけた浮選機に 移し, 10 分間空気混和を行なつた。空気混和終了後, 直ち に直径 $7 \mathrm{~cm}$ のブフナー漏斗を用い，吸引洰過した。その後， 洰液中の As , スラッジ中の $\mathrm{Fe}, \mathrm{Zn}, \mathrm{Cd}$ の分析を行なつ た。スラッジ中の $\mathrm{Fe}, \mathrm{Zn}, \mathrm{Cd}$ を分析したのは水分に含 まれるこれらの量も合わせて評価するためである。Asはモ リブデン青法, $\mathrm{Fe}$ は重クロム酸カリウム滴定法, $\mathrm{Zn}, \mathrm{Cd}$ は原子吸光法により分析した。スラッジの含水率は, スラ ッジの乾燥前後の重量から求めた。乾燥は $110^{\circ} \mathrm{C} て ゙ 3$ 時間 行なつた。また, 洰液の濁度の一つの目安として, 10 倍希 釈液に対して波長 $500 \mathrm{~mm}$ に扔ける透過率を測定した。

\section{3. 実験結果および考察}

浸出液を炭カル共存下で空気酸化し, 生成する水酸化第 二鉄にAs(III)共沈させ除去する場合, $\mathrm{Fe}^{2+}, \mathrm{Zn}^{2+}, \mathrm{Cd}^{2+}$ の損失をできるだけ避けるために，水酸化第二鉄の生成量 を必要最低量に抑え，しかも低 $\mathrm{pH}$ で行なうことが望まし い。As(倓あるいはAs(V)の水酸化第二鉄による共沈除去に 関する研究は多く行なわれているが, (4),6) 8) 高温下で, 比較的高濃度のAs(倓)共沈除去に関する研究は見当たらない。 そこで, 常温と $80^{\circ} \mathrm{C} \mathrm{As}($ III) $300 \mathrm{mg} / l$ 溶液に対し, 所定濃度 になるように $\mathrm{Fe}_{2}\left(\mathrm{SO}_{4}\right)_{3}$ を添加し, $\mathrm{NaOHで} \mathrm{pH}$ 調整し ${ }^{\mathrm{b})} 30$ 分間マグネチックスターラて攪拌した後, No. 5 C 洰紙 ${ }^{c)}$

第 1 表 実験資料の組成

\begin{tabular}{|c|c|c|c|}
\hline & 人I溶液 & 脱 銅 液 & 一次中和水 \\
\hline $\mathrm{As}(\mathrm{mg} / \mathrm{l})$ & 100 & $325^{*}$ & 69.8 \\
\hline 全 $\mathrm{Fe}(\mathrm{g} / \mathrm{l})$ & & 32.8 & - \\
\hline $\mathrm{Fe}^{2+}(\mathrm{g} / \mathrm{l})$ & 30 & 32.2 & 31.6 \\
\hline $\mathrm{Zn}(\mathrm{g} / \mathrm{l})$ & 60 & 60.8 & 60.7 \\
\hline $\mathrm{Cd}(\mathrm{mg} / \mathrm{l})$ & 250 & 163 & 162 \\
\hline $\mathrm{pH}$ & 3.8 & 1.0 & 4.5 \\
\hline
\end{tabular}

日本鉱業会誌/96 $1103\left({ }^{\prime} 80-1\right) 25<25>$ 

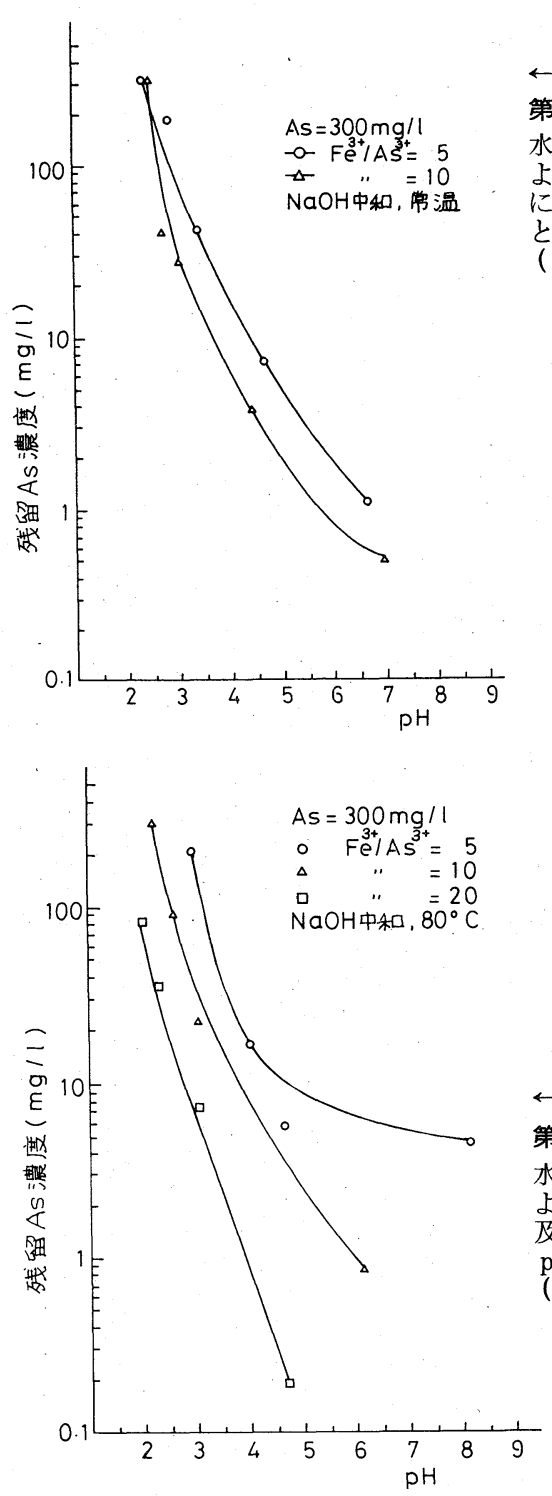

で洰過したときの洰液に残留しているAs 濃度を測定した。 第 1 図は常温に扔ける結果であるが，七鉄比 ${ }^{\mathrm{d}}$ (As に対す る $\mathrm{Fe}^{3+}$ の重量比)が 5,10 のいずれの場合も残留As濃度 は $\mathrm{pH}$ が上昇するにつれて急激に低下しており， $\mathrm{pH} 4$ 付 近で七鉄比が 5 のときは $15 \mathrm{mg} / l$, 七鉄比が 10 のときは $6 \mathrm{mg} / l$ 程度まで低下している。第 2 図は $80^{\circ} \mathrm{C}$ における 結果である。液温 $80^{\circ} \mathrm{C}$ 場合, 常温にくらべて, $\mathrm{pH}$ の上 昇にともなう残留As 濃度の低下は若干緩慢であるが, $\mathrm{pH}$ 4 付近で, 七鉄比が 5,10 および 20 のとき,それぞれ 15,10 および $1 \mathrm{mg} / l$ 程度まで低下しており, $80^{\circ} \mathrm{C}$ の高 温でも水酸化第二鉄によるAs(III) の共沈除去が可能である ことを示している。

第 3 図は人工溶液に対し, 種々の量の炭カルを添加し,

b）水酸化第二鉄によるAsの共沈除去効果は用いる中和剤によつて差異 はないことが認められている。

c）水酸化第二鉄の沪過には通常 No. 5 Aの沪紙が用いられているが, 本 実験に扔いては, とくに $80^{\circ}$ Cの場合, No.5A沪紙では洰夜に著し い濁りが認められたので，No. 5 C沪紙を使用した。

d）本来鉄七比というべきであるが，語感の点から七鉄比の言葉が使わ れている。
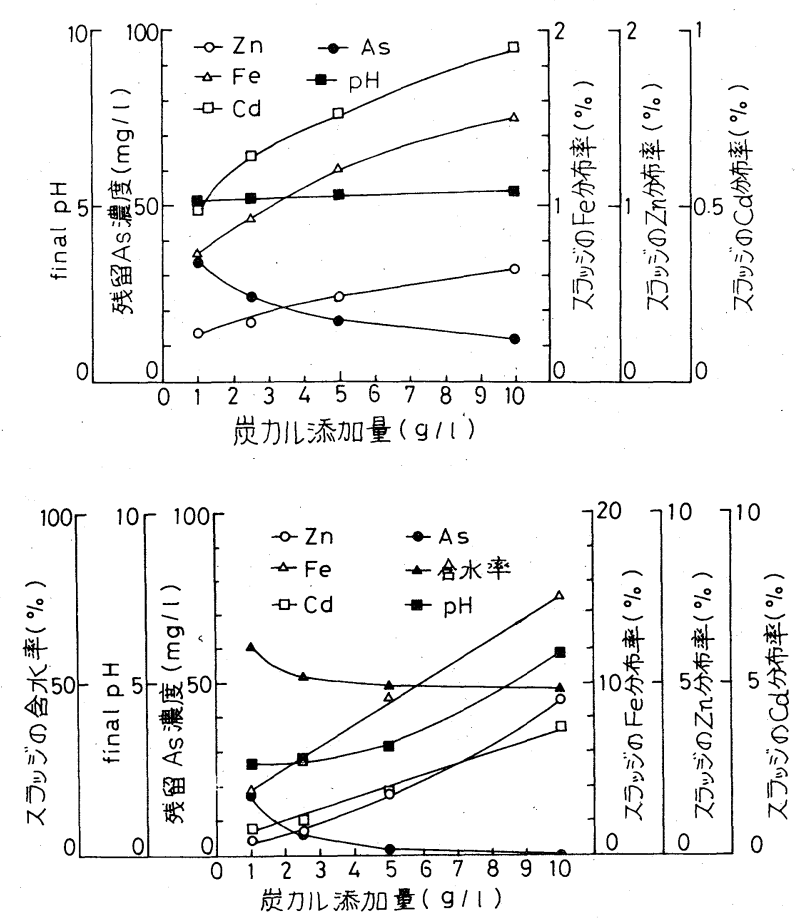

常温で 10 分間空気酸化を行なつたときの結果である。炭力 儿添加量が増加するとともにスラッジの Fe 分布率が高く なり, $\mathrm{Fe}^{2+} \rightarrow \mathrm{Fe}^{3+}$ の酸化反応がより進行することを示し ており，それとともに残留As 濃度も低下してくる。しかし， 常温の場合, 以下に述べる $80^{\circ} \mathrm{C}$ の場合にくらべて, $\mathrm{Fe}^{2+} \rightarrow$ $\mathrm{Fe}^{3+}$ の酸化速度は遅く, 炭カル添加量 $1 \sim 2.5 \mathrm{~g} / l$ のとき は水酸化第二鉄の生成量は小で, 残留 $\mathrm{As}$ 濃度は $20 \mathrm{mg} / l$

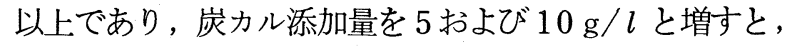
残留As 濃度はそれぞれ 18 および $12 \mathrm{mg} / l$ に低下してく る。

第 4 図は $80^{\circ} \mathrm{C}$ の工溶液を炭カル共存下で 10 分間空気 酸化したときの結果である。 $80{ }^{\circ} \mathrm{C}$ で空気酸化後, No.5C 洰紙で洰過する際, 洰液に濁りがみられたので, 洰液を再 び洰紙上に戻して2 回の沪過操作をおこなつた。なお, 常 温の場合には 1 回の沪過で透明な洰液が得られた。 $80^{\circ} \mathrm{C} の$ 場合には $\mathrm{Fe}^{2+} \rightarrow \mathrm{Fe}^{3+}$ の酸化反応が活発に行なわれ, 炭力 ル添加量が少ないときでも，かなりの $\mathrm{Fe}$ 分がスラッジに分 布している。すなわち, 炭カル添加量が $1 \mathrm{~g} / l$ のときでス ラッジの Fe 分布率は $3.9 \%$ であり，このうち水分に含まれ る $\mathrm{Fe}^{2+}$ 分を差し引くと $\mathrm{Fe}^{3+}$ 分布率は $3.4 \%$ となり, この 值から七鉄比は 10 となる。しかし, この場合, $\mathrm{pH}$ 落 2.7 まで低下するため , 残留As 濃度を十分に低下させることが

e) 化学分析操作において, 水酸化第二鉄の汇過の際, 液温を上げて, その沪過特性の改善を計つているが, 本実験では, 後に敷䘕するよ うに液温が高くなると沪過特性が劣化した。

f) 炭カル共存下での $\mathrm{Fe}^{2+} \rightarrow \mathrm{Fe}^{3+}$ の空気酸化は液温により著しく影響 され，液温が高いほど反応速度が大きいことが認められている。

g) 炭カル共存下での $\mathrm{Fe}^{2+} \rightarrow \mathrm{Fe}^{3+}$ の空気酸化は次式により進行すると 考えられる。 $2 \mathrm{FeSO}_{4}+\frac{1}{2} \mathrm{O}_{2}+2 \mathrm{CaCO}_{3}+3 \mathrm{H}_{2} \mathrm{O} \rightarrow$ $2 \mathrm{Fe}(\mathrm{OH})_{3}+2 \mathrm{Ca} \mathrm{SO}_{4}+2 \mathrm{CO}_{2}$ なお, $80^{\circ} \mathrm{C}$ の場合, 炭カル添加量 $2.5 \mathrm{~g} / l$ まではスラッジ中の $\mathrm{Fe}$ 分布率から計算すると理論量以上の $\mathrm{Fe}^{2+}$ が $\mathrm{Fe}^{3+}$ に酸化されている。 
できないが，炭カル添加量を増すと， $\mathrm{Fe}^{2+}$ の酸化が促進さ れるとともに, $\mathrm{pH}$ が上昇して来て, 残留As濃度も著しく 低下してくる。すなわち, 炭カル添加量が $2.5 \mathrm{~g} / l$ のとき

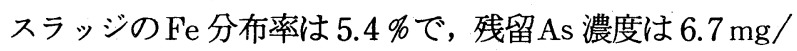
$l$, 炭カル添加量が $5 \mathrm{~g} / l$ のときスラッジの Fe 分布率は $9.2 \%$ で, 残留As 濃度は $1.2 \mathrm{mg} / l$ まで低下する。この際,

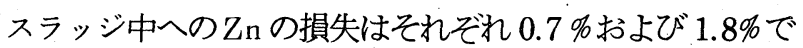
あり， $\mathrm{Cd}$ のそれは $1.0 \%$ および $1.9 \%$ \%゙る。

以上の人工溶液の結果から, 液温 $80^{\circ} \mathrm{C}$ 場合, 炭カル共 存下で 10 分間程度の空気酸化することにより $\mathrm{Fe}^{2+} \rightarrow \mathrm{Fe}^{3+}$ の酸化反応が活発に行なわれ，残留As 濃度を十分に低下さ せ得ることが分かつたので，以下，一次中和水に対して同 様の実験を行なつた。なお，前述したように，常温の場合 にくらべて液温 $80^{\circ} \mathrm{C}$ の場合にはスラッジの洰過特性が著 しく劣化することが認められたので，とくに洰過特性に注 目して実験を行なつた。

第 5 図は $80^{\circ} \mathrm{C}$ の一次中和水に対して種々の量の炭カル を添加し，10 分間空気酸化を行なつた結果である。なおこ の場合も 1 回の洰過では洰液に濁りが認められたので， 2 回の洰過操作を行なつた。同図の結果は第 4 図の人工溶液 に対する結果とほぼ同様であるが, スラッジ中へのZn， $\mathrm{Cd}$ の損失が若干大きくなつている。すなわち, 炭カル添 加量 $2.5 \mathrm{~g} / l$ のとき, スラッジに損失する $\mathrm{Fe}, \mathrm{Zn}, \mathrm{Cd}$ は それぞれ， $5.3 ， 1.2$ および $1.5 \%$ で, 残留As 濃度は $5 \mathrm{mg}$ $/ l$ であり, 炭カル添加量が $5 \mathrm{~g} / l$ のときはスラッジに損 失する $\mathrm{Fe}, \mathrm{Zn}, \mathrm{Cd}$ はそれぞれ $8.3,2.6$ および 2.9 であり, 残留 $\mathrm{As}$ 濃度は $0.6 \mathrm{mg} / l$ である。

第 6 図は $80^{\circ} \mathrm{C}$ の一次中和水を炭カル共存下で空気酸化

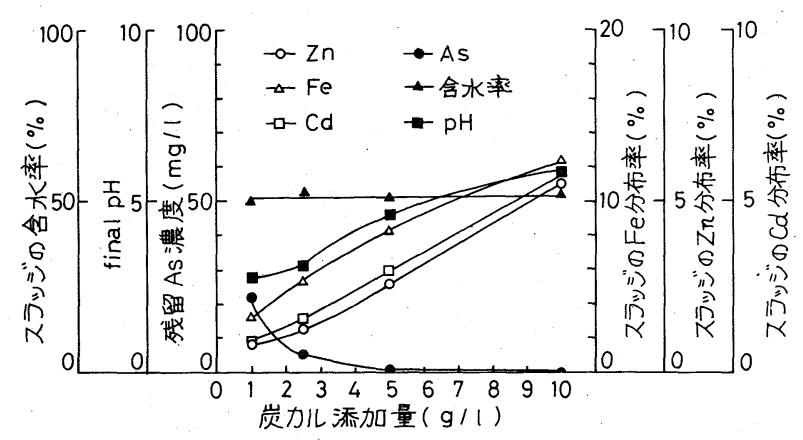

第5図 $80^{\circ} \mathrm{C}$ における一次中和水の炭カル 共存下での空気酸化による脱 As

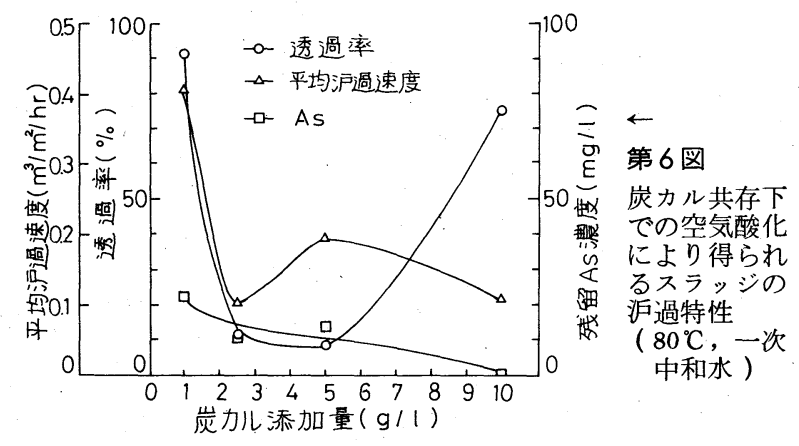

した後, 1 回目の洰過をした際の平均洰過速度, 洰液の 10 倍希釈液の透過率および残留As濃度を示したものであ る。炭カル添加量が $1 \mathrm{~g} / l$ のときは平均洰過速度は $0.4 \mathrm{~m}^{3}$ $/ \mathrm{m}^{2} / \mathrm{hr}$ と必ずしも大きくはないが，透過率は良好であり， 残留As 濃度は 2 回洰過した場合とほとんど変わらず, $20 \mathrm{mg}$ $/ l$ 程度である。炭カル添加量を $2.5 \mathrm{~g} / l, 5 \mathrm{~g} / l$ に増す と, 平均洰過速度が $0.1 \sim 0.2 \mathrm{~m}^{3} / \mathrm{m}^{2} / \mathrm{h}$ と低下するとともに, 透過率も著しく劣化してくる。その場合の残留 As 濃度は 2 回洰過した場合にくらべて高く,それぞれ $10.2 \mathrm{mg} / l$ お よび $13.8 \mathrm{mg} / l$ となつている。炭カル添加量を $10 \mathrm{~g} / \mathrm{l}$ ま で增すと，洰過速度の改善は認められないが，洰液の透過 率は良好となり，残留As 濃度は $0.9 \mathrm{mg} / l$ まで低下する。 ただし，この場合，第 5 図から，スラッジ中への $\mathrm{Zn}, \mathrm{Cd}$ の損失はかなり大になることが予想される。以上の結果よ $\eta$, 液温 $80^{\circ} \mathrm{C}$ の一次中和水に対し, 炭カル $2.5 \mathrm{~g} / l$ 以上 添加し， 10 分間空気酸化した後，1回の沪過操作を行な うことにより, 残留As 濃度を $14 \mathrm{mg} / l$ 以下に低下させ得 るが, 平均洰過速度が $0.1 \sim 0.2 \mathrm{~m}^{3} / \mathrm{m}^{2} / \mathrm{hr}$ と小さいという 欠点を有している。 そこで, 高分子凝集剤によるスラッジ の沪過特性の改善を試みた。

第 7 図は一次中和水に対し, 炭カル添加量を $5 \mathrm{~g} / l$ とし, $80^{\circ} \mathrm{C}$ で 10 分間空気酸化した後, 高分子凝集㓮としてセパ ランNP10を添加して1 回洰過した場合の平均洰過速度, 洰液の 10 倍希釈液の透過率および残留As濃度を示してい る。同図からセパランNP10の添加により, 透過率は著し く増加し, セパランNP 10 を $5 \mathrm{mg} / l$ 添加すると残留As 濃度は $4 \mathrm{mg} / l$ まで低下するが, 沪過速度の改善は認めら れない。

炭カル中和は石灰中和に比して得られる殿物の沈降速度 が大で, 沈降容積が小さいという利点をもつているが，こ の炭カル中和の有利性は溶液中の $\mathrm{Fe}^{3+}$ 濃度がある範囲内に あるときにのみ認められ, $\mathrm{Fe}^{3+}$ 濃度が $2.5 \sim 3.0 \mathrm{~g} / l$ 以上 になると次第に沈降特性が劣化してくる。 この結果は常温 の硫酸第二鉄溶液に炭カルを添加したときに得られたもの であり, 本実験のように高温で, しかも炭カル共存下で空

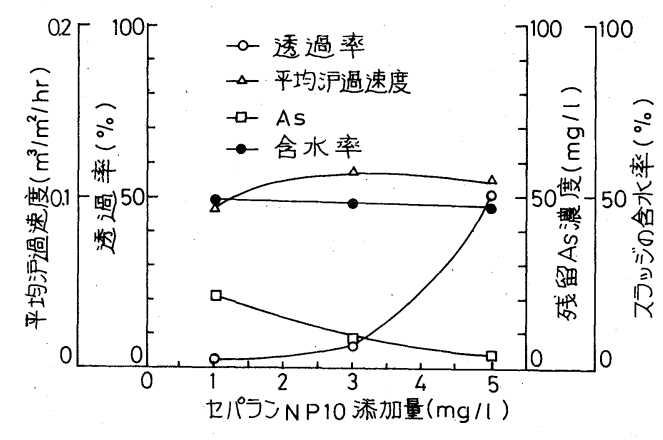

第7図 炭カル共存下での空気酸化により得 られるスラッジの沪過性に及ぼす凝 集剂の影響 $\left(80^{\circ} \mathrm{C}\right.$, 一次中和水)

h）なお，常温の場合には，生成スラッジ量も少ないが，スラッジの平 均沪過速度は $0.5 \sim 0.6 \mathrm{~m}^{3} / \mathrm{m}^{2} / \mathrm{hr}$ であつた。 


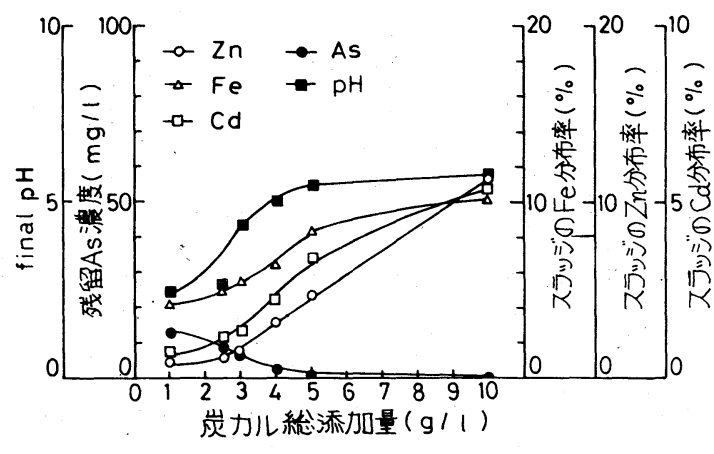

第8図炭カル共存下 $(1 \mathrm{~g} / l)$ で空気酸化の後, さらに炭カルを添加し，蕒汼したときの 脱 $\mathrm{As}\left(80^{\circ} \mathrm{C}\right.$, 一次中和水)

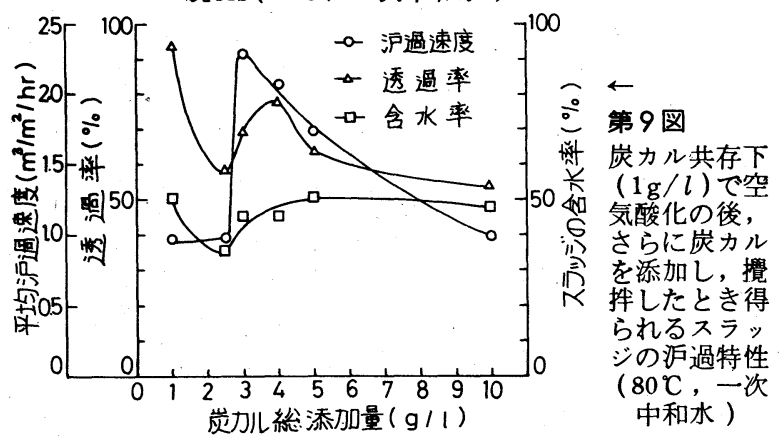

気酸化する場合にも，上記の結果がそのまま当てはまると は限らないが, 炭カル添加量 $2.5 \mathrm{~g} / l$ 以上で洰過特性が劣 化する原因の 1 つとして $\mathrm{Fe}^{3+}$ 濃度が最適範囲を上回つてい ることが考えられる。一方, 前述したように, 炭カル添加 量が $1 \mathrm{~g} / l$ と少ないとき, $\mathrm{pH}$ が低いため, 満足すべき残 留As濃度が得られないが, 七鉄比としては十分な值に達し ているので, 炭カル添加量を $1 \mathrm{~g} / l$ として 10 分間空気酸 化を行なつた後, さらに, 種々の量の炭カルを添加し, 空 気を導入せずに 10 分間攪找を行なうことにより,水酸化第 二鉄の生成量を抑え,残留As 濃度の低下と沪過特性の改善 が可能であるかについて検討した。第 8 図および第 9 図は その結果であり, 横軸の炭カル添加量は酸化時に添加した 量と酸化後に添加した量との合量で示している。第 8 図か らわかるように, 空気の導入を中止しても, 機械攪找を行 なうだけで $\mathrm{Fe}^{2+}$ の酸化反応が進行し, 炭カル添加量の増加 とともにスラッジの Fe 分布率が高くなり,この点では期待 されるような結果は得られなかつが，後述するように沪 過特性を著しく改善することができる。したがつて，1回 の沪過で洰液は比較的透明となるため, 第 6 図の空気酸化 後, 直ちに沪過を行なつた場合にくらべ,残留As 濃度を大 幅に低下させることができ, 第 5 図の 2 回沪過を行なつた 場合に匹敵する値を得ることができる。すなわち, 炭カル 添加量が $3 ， 4$ および $5 \mathrm{~g} / l$ のとき, 残留As 濃度はそれ ぞれ $6.0,1.5$ および $1.0 \mathrm{mg} / l$ まで低下する。一方スラッ ジ中への Fe, Zn, Cd の損失は, 炭カル添加量が $3 \mathrm{~g} / l$ まではゆるやかに増加するが, それ以上の添加量で急激に 増加する。すなわち, 炭カル添加量が $3 \mathrm{~g} / l$ のときは $\mathrm{Fe}$, $\mathrm{Zn}, \mathrm{Cd}$ の損失はそれぞれ 5.4, 1.6, $1.3 \%$ あるるが, 4 $\mathrm{g} / l$ のときはそれぞれ $6.5,3.1,2.3 \%$ と増加し, $5 \mathrm{~g} / l$ のときはそれぞれ $8.1 ， 4.1 ， 3.4 \%$ となる。第 9 図はスラ

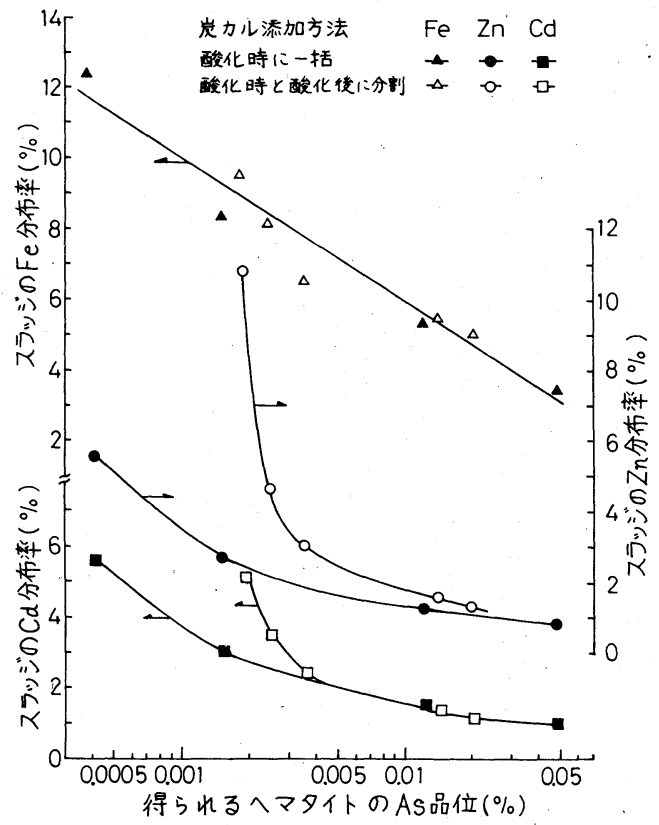

第10図 炭カル共存下での空気酸化による脱Asに扔けるスラッ ジ中への $\mathrm{Fe}, \mathrm{Zn}, \mathrm{Cd}$ の損失と洰夜から得られるへマタ イトのAs品位の関係 $\left(80^{\circ} \mathrm{C}\right.$, 一次中和水)

ッジの沪過特性を示しているが，スラッジの含水率は炭カ ル添加量に関係なく, 約 $50 \%$ で, 第 5 図の空気酸化後, 2 回の洰過を行なつた場合と同程度である。平均沪過速度は 空気酸化後炭カルを添加せずに 10 分間攪挥するだけで約 2 倍に増加し, 酸化後, 炭カルを $2 \sim 3 \mathrm{~g} / l$ 添加すると ( 総添加量 $3 \sim 4 \mathrm{~g} / l$ ), さらにその 2 倍以上増加してお り, $2.1 \sim 2.3 \mathrm{~m}^{3} / \mathrm{m}^{2} / \mathrm{hr}$ となる。この值は第 6 図の空気酸 化後, 直ちに沪過をする場合のそれの 10 倍 以上となつて いる。また, 透過率もその程度の炭カル添加量で比較的高 い值が得られており，肉眼ではほとんど濁りは認められな い。なお, 空気酸化後, 炭カルをさらに添加するときと, 空気酸化時に一括して炭カルを添加するときとではほぼ同 量の水酸化第二鉄が生成しており, 上記の洰過特性の改善 は前述の予想とは異なり，水酸化第二鉄の生成量の差異に よるものでなく，他の原因によるものと考えられるが, そ それについては今後の検討にまたねばならない。

以上の結果から, 酸化時に少量の炭カルを添加し, その 後炭カルを再び添加すると, 酸化時に炭カルを一括添加す るよりも，スラッジの沪過速度を著しく高め得ることがわ かつた。本方式で脱Asした液からへマタイトを沈殿させた 場合の As 品位とスラッジ中への Fe, Zn, Cd の損失を関係 づけて, 上記の 2 種類の炭カル添加法を比較すると, 第 10 図のようになる。なお，酸化時に炭カルを一括添加した場 合の結果は 2 回沪過したときのそれで示している。同図か ら, $\mathrm{Fe}$ の損失に関しては炭カルの添加方法によつては明ら かな差異はなく, ヘマタイトのAs 品位とよい相関関係が認

i ) (a)少量の炭カル共存下で空気酸化後, さらに炭カルを添加する方法 と, (b)空気酸化時に炭カルを一括して添加する方法との状況の差異 として, (a)の場合には酸化により pH が低下したところに炭カルが さらに添加されて摫䢁が行なわれること，また(a)の場合は炭カル添 加量 $3 \sim 5 \mathrm{~g} / l$ の沪過特性が良好なときの $\mathrm{pH}$ は(b)の場合よりも高 いことなどがあげられる。 
められる。また，ZnとCdの損失に関しても, へマタイト の As 品位が $0.05 〜 0.005 \%$ 範囲にわたつては炭カル の添加方法により大きな差異は認められない。

\section{4. 結論}

以上, 亜鉛残渣浸出液の脱Asについて, 炭カル共存下で の $\mathrm{Fe}^{2+}$ の空気酸化により生成される水酸化第二鉄に共沈さ せる方法を検討した結果をまとめると次のようである。

(1) 高温で, しかも比較的高濃度 $(300 \mathrm{mg} / l)$ のAs (III) の水酸化第二鉄による共沈除去は, 常温の場合にくらべ若 干効果が劣るが, $\mathrm{pH} 4$ で, 鉄比が 10 のとき, 残留 As 濃度を $1.0 \mathrm{mg} / l$, 七鉄比が 20 で $1 \mathrm{mg} / l$ まで低下させる ことができる。

(2) 常温の場合, $1 \sim 2.5 \mathrm{~g} / l$ の炭カルの共存下での $\mathrm{Fe}^{2+}$ の空気酸化は速度が遅く, 10 分間の酸化時間 では水 酸化第二鉄の生成量は小で, 残留As 濃度を $20 \mathrm{mg} / l$ 以下 にするには炭カルを $5 \mathrm{~g} / l$ 以上添加しなければならない。

(3) $80^{\circ} \mathrm{C}$ の場合, 炭カル共存下での $\mathrm{Fe}^{2+}$ の空気酸化は 速やかに進行し, 炭カル $1 \mathrm{~g} / l$ の共存で, 10 分間空気酸化 するとAsを共沈するのに十分な水酸化第二鉄を生成するが, $\mathrm{pH}$ が低いため残留 $\mathrm{As}$ 濃度は $20 \mathrm{mg} / l$ 程度である。炭カ ル添加量を 2.5〜 $5 \mathrm{~g} / l$ に増すと,水酸化第一鉄の生成量が 増加するとともに $\mathrm{pH}$ が上昇して来て, As 濃度は 10.2 $13.8 \mathrm{mg} / l$ まで低下する。しかし, この場合, スラッジの 沪過速度が $0.1 \sim 0.2 \mathrm{~m}^{3} / \mathrm{m}^{2} / \mathrm{hr}$ と遅い上,洰液に濁りが認 められる。なお，これらの洰液を再び洰紙上に戻して洰過 すると As 濃度は $6.7 \sim 1.2 \mathrm{mg} / l$ まで低下する。

(4) 液温が $80^{\circ} \mathrm{C}$ の場合, 炭カル共存下で空気酸化後, 高
分子凝集剤であるセパランNP10を添加して沪過すると， 洰液の濁りは大幅に減少するが, 洰過速度の改善は認めら れない。

(5) 液温が $80^{\circ} \mathrm{C}$ 場合, $1 \mathrm{~g} / l$ の炭カルの共存下で空 気酸化した後, さらに炭カルを添加することにより, スラ ッジの沪過特性が著しく改善される。炭カルの総添加量が $3 \sim 4 \mathrm{~g} / l$ で, 残留As 濃度は $6.0 \sim 1.5 \mathrm{mg} / l$ まで低下し, この洰液からへマタイトを作つたとするとそのAs 品位は $0.014 \sim 0.0035 \%$ と計算される。この場合のスラッジ中 へのFe, $\mathrm{Zn}, \mathrm{Cd}$ の損失はそれぞれ， $5.4 \sim 6.5,1.6$ 3.1 , および $1.3 \sim 2.3 \%$ \%あるなお, この場合のスラッ ジの沪過速度は $2.1 \sim 2.3 \mathrm{~m}^{3} / \mathrm{m}^{2} / \mathrm{hr}$ である。

最後に，本研究を遂行するに当たり，多大の御支援を頂い た同和鉱業株式会社ならびに秋田製鍊株式会社関係各位に 深謝する次第である。

\section{参考文 献}

1）許東栄：工業用水, No.123, p.21（1968）

2) 山手昇: 衛生試験所報告, No. 80, p.66 (1962)

3) S. Rosehart and J. Lee, Can. Min. J., Vol.97, No.6, p. 53 ( 1972$)$

4）公害防止の技術と法規 (水質論), P. 220 , 産業公害防止協会 (1972)

5）恵美元明・山田富三・日野隆：日釷誌，90，360（1974）

6) D. Laguitton: CIM Bull., Vol.69, No.9, p.105 (1976)

7）宮本乙次郎·杉之原幸夫·柳ヶ瀬勉：日鉱誌， 89，101（1973）

8) 戸沢一光・西村忠久：日鉱誌, 92, 809 (1976)

9）下飯坂潤三・松岡功・森秀樹：昭和 53 年度日本釷業会春季大会講 演要旨集, P. 40

10）下飯坂潤三：日鉱誌, 85,755 (1969)

11）高橋知行：昭和 47 年度東北大学博士論文

\section{Removal of Arsenic from the Leach Solution of the Residue in Zinc Hydrometallurgy} by Junzo SHIMOIIZAKA ${ }^{1}$, Isao MATSUOKA ${ }^{2}$, Hiroshi NAKAZAWA $^{3}$,
Hisashi YOSHIDA ${ }^{4}$ and Takuji OTSUKA

In the hydrometallurgical treatment of the zinc leach residue, arsenic in the zinc concentrate is condensed into iron precipitate such as hematite and goethite.

So it is difficult to utilize such iron precipitate as raw material for iron and/or its compounds.

From this point of view, the removal of arsenic from the leach solution prior to iron removal stage has been investigated by means of coprecipitation with ferric hydroxide which is formed by oxidizing a part of $\mathrm{Fe}^{2+}$ ion in the solution. The oxidation of $\mathrm{Fe}^{2+}$ ion was carried out by aeration under the coexistence of suitable amounts of calcium carbonate, using a Denver type flotator.

Sample solution contained $69.8 \mathrm{mg} / \mathrm{l}$ of $\mathrm{As}(\mathrm{III}), 31.6 \mathrm{~g} / 1$ of $\mathrm{Fe}^{2+}, 60.7 \mathrm{~g} / 1$ of $\mathrm{Zn}^{2+}$ and $162 \mathrm{mg} / 1$ of $\mathrm{Cd}^{2+}$. The $\mathrm{pH}$ and temperature of the solution were 4.5 and $80^{\circ} \mathrm{C}$, respectively.

The concentration of $\mathrm{As}$ (III) in the filtrate was reduced to 14 to $10 \mathrm{mg} / \mathrm{l}$ by aeration for $10 \mathrm{~min}$ under the coexistence of 2.5 to $5 \mathrm{~g} / 1$ of calcium carbonate and by filtration with No.5C paper filter. But, in this case the filtration rate was very low and the filtrate was turbid. When filtration was repeated, the concentration of As(III) in the filtrate was reduced to 6.7 to $1.2 \mathrm{mg} / \mathrm{l}$ and the filtrate was transparent. The turbidity of the filtrate was remarkably reduced by using a polymeric flocculant, but the filtration rate was unchanged.

When the solution was aerated for $10 \mathrm{~min}$ under the coexistence of a small amount of calcium carbonate $(1 \mathrm{~g} / \mathrm{l})$ and then agitated for 10 min without aeration after adding 2 to $3 \mathrm{~g} / 1$ of calcium carbonate, the filtration characteristics were then agitated for 10 min without aentration of $\mathrm{As}(\mathrm{III})$ in the filtrate was reduced to 6.0 to $1.5 \mathrm{mg} / 1$. If hematite is precipitated considerably improved and the concentration of As(III) in the filtrate was reduced to 6.0 to $1.5 \mathrm{mg} / 1$. If hematite is precipitated
from this filtrate, its arsenic content will be 0.014 to $0.0035 \%$. In this case, the loss of $\mathrm{Fe}^{2+}, \mathrm{Zn}^{2+}$ and Cd $\mathrm{Cd}^{2+}$ was 5.4 to $6.5,1.6$ to 3.1 and 1.3 to $2.3 \%$, respectively and the filtration rate was 2.1 to $2.3 \mathrm{~m}^{3} / \mathrm{m}^{2} / \mathrm{hr}$.

1. Prof., Dr., Faculty of Engineering, Tohoku Univ.

3. Research Assistant, Faculty of Engineering, Iwate Univ.

5. General Manager, Iijima Refinery, Akita
2. Assoc. Prof., Dr., Faculty of Engineering, Tohoku Univ.

4. Faculty of Engineering, Tohoku Univ. 